\title{
Experimental carcinogenesis on the oropharyngeal mucosa of rats with hydrochloric acid, sodium nitrate and pepsin ${ }^{1}$
}

\author{
Carcinogênese experimental na mucosa orofaríngea de ratos com ácido clorídrico, nitrato \\ de sódio e pepsina
}

\author{
André Del Negro", Marina Raquel Araújo ${ }^{\mathrm{II}}$, Alfio José TincaniII, Luciana Meirelles ${ }^{\mathrm{IV}}$, Antônio Santos Martins ${ }^{\mathrm{III}}$, Nelson \\ Adami Andreollov \\ ${ }^{\mathrm{I}}$ Fellow PhD degree, Attending surgeon, Division of Head and Neck, Department of Surgery, UNICAMP, Brazil. \\ ${ }^{\text {II }}$ Biologist, Laboratory of Enzymology and Experimental Carcinogenesis, UNICAMP. Brazil \\ III PhD, Associate Professor, Division of Head and Neck, Department of Surgery, UNICAMP, Brazil. \\ ${ }^{\text {IV }} \mathrm{PhD}$, Assistant Professor, Department of Pathology, UNICAMP, Brazil. \\ v PhD, Full Professor, Gastroenterological Surgery, Chairman of the Department of Surgery, UNICAMP, Brazil.
}

\begin{abstract}
Purpose: To investigate the carcinogenic action of hydrochloric acid, pepsin and sodium nitrate on the oropharyngeal mucosa of rats, simulating the reflux of gastric contents. Methods: Eighty-two Wistar rats were divided in seven groups and submitted to 2 or 3 weekly applications of hydrochloric acid, pepsin and sodium nitrate on the pharyngeal mucosa during six months. Study groups comprised 12 animals each. Rats in groups I and II were submitted to 2 (GI) or 3 (GII) weekly applications of $0.1 \mathrm{~N}$ hydrochloric acid. Groups III and IV were submitted to 2 (GIII) or 3 (GIV) weekly applications of $0.1 \mathrm{~N}$ hydrochloric acid solution with pepsin. Groups V and VI were submitted to $2(\mathrm{GV})$ or $3(\mathrm{GVI})$ weekly applications of $0.1 \mathrm{~N}$ hydrochloric acid and treated with daily nitrate diluted in water. Group VII consisted of 10 animals submitted to 2 weekly applications of filtered water. Results: No dysplasia, intra-epithelial neoplasia or invasive carcinomas were detected. Inflammatory changes were observed in varying degrees and mast cells were more common in Groups V and VI ( $p=0.006)$. Conclusion: The data of the current study could not corroborate the hypothesis that gastroesophageal and pharyngolaryngeal refluxes are carcinogenic factors to the laryngopharyngeal mucosa, and more studies are necessary in the future.
\end{abstract}

Key words: Gastroesophageal Reflux. Hydrochloric Acid. Nitrates. Carcinoma, Squamous Cell. Rats.

\section{RESUMO}

Objetivo: Investigar a ação carcinogênica do ácido clorídrico, pepsina e nitrato de sódio na mucosa orofaríngea de ratos, simulando o refluxo do conteúdo gástrico à mucosa do faringo-laringea. Métodos: Oitenta e dois ratos Wistar foram divididos em 7 grupos e submetidos a 2 ou 3 aplicações semanais de ácido clorídrico, pepsina e nitrato de sódio na mucosa orofaríngea durante 6 meses. Os grupos de estudo envolveram 12 animais cada. Os ratos nos grupos I e II foram submetidos à 2 (GI) ou 3 (GII) aplicações semanais de ácido clorídrico 0,1N. Nos grupos III e IV foram 2 (GIII) ou 3 (GIV) aplicações semanais de ácido clorídrico e pepsina. Nos grupos V e VI foram 2 (GV) ou 3 (GVI) aplicações semanais de ácido clorídrico além da oferta de nitrato diluído em água diariamente. Grupo VII era composto por 10 animais submetidos a 2 aplicações semanais de água filtrada. Resultados: Não se observou displasia, neoplasia intra-epitelial ou neoplasia invasora. Alterações inflamatórias em graus variados foram observadas, com infiltrado mastocitário mais intenso nos grupos V e VI. $(\mathrm{p}=0,006)$. Conclusão: Os dados do presente estudo não confirmam a hipótese que o refluxo gastro-esofágico e faringo-laringeo são fatores carcinogênicos para a mucosa laringo-faringea e mais estudos são necessários no futuro.

Descritores: Refluxo Gastroesofágico. Ácido Clorídrico. Nitratos. Carcinoma de Células Escamosas. Ratos.

${ }^{1}$ Research performed at the Laboratory of Enzymology and Experimental Carcinogenesis, School of Medical Sciences - UNICAMP, Campinas, Sao Paulo, Brazil. 


\section{Introduction}

The association of smoking and alcoholism with malignant neoplasms of the upper aerodigestive tract has been known for many years ${ }^{1-3}$. Other risk factors have been of increasing interest in the study of the pathogenesis of squamous cell carcinomas (SCC) in this region, especially the gastroesophageal (GER) and pharyngolaryngeal (PLR) refluxes, hydrochloric acid being the main irritating agent of the mucosa.

In oropharyngeal and laryngeal SCC, the development of this neoplasia is directly related to drinking and smoking. Several authors have shown the relationship existing between the gastroesophageal reflux disease (GERD) and the development of SCC $\mathrm{SC}^{4-19}$ in the pharynx and larynx. Some authors have confirmed this hypothesis ${ }^{20-26}$ in animal studies, whereas some others have not ${ }^{27}$.

When nitrates present in salivary secretion come into contact with the acid $\mathrm{pH}$ of the stomach, they can be converted into nitrosamines, which co-promote esophageal carcinogenesis $^{28-29}$, possibly acting in upper parts of the aerodigestive tract as well.

Due to the unmistakable presence of upper aerodigestive tract SCC in non-alcoholics and non-smokers ${ }^{30}$, it is clear that the study of other causal factors of the disease may contribute to a better understanding of the pathogenesis and advance in its treatment.

In this study we will evaluate the carcinogenic action of hydrochloric acid associated with pepsin, with and without addition of sodium nitrate when instilled in the oropharyngeal mucosa of young male Wistar rats, simulating the injury caused by gastroesophageal and pharyngolaryngeal reflux on the mucosa of the upper airway and digestive tracts in humans

The objective is to show the carcinogenic action of hydrochloric acid on the oropharyngeal mucosa of Wistar rats, potentialized by pepsin, associated or not with sodium nitrate, with the application of these substances directly on the pharyngolaryngeal mucosa of the rats, simulating the reflux of the gastric contents to the laryngopharynx and to develop an experimental model of induction of malignant neoplasias in the upper aerodigestive tract of Wistar rats.

\section{Methods}

Eighty-two young randomly chosen male Wistar rats weighing between $300 \mathrm{~g}$ and $400 \mathrm{~g}$ were studied. The animals were placed in cages lined with sawdust and kept at the Experimental Surgical Center of the Department of Surgery at UNICAMP, Brazil. The committee on ethics in animal experimentation gave its favorable opinion to the experiment.

Water was available ad libitum to all animals, including those treated with the sodium nitrate solution. Each animal was given a specific number marked with a hydrographic pen on its tail, and were divided into seven groups.

Hydrochloric acid was used in a $0.1 \mathrm{~N}$ solution, the same concentration found in the human stomach. Pepsin was added to simulate the gastric contents during the digestive process, based on the study by Adams et al. ${ }^{20}$.
Group I consisted of twelve animals submitted three times weekly to the application of a solution of $0.1 \mathrm{~N}$ (normal) hydrochloric acid directly on the laryngopharyngeal mucosa.

Group II consisted of twelve animals submitted twice weekly to the application of a $0.1 \mathrm{~N}$ hydrochloric acid solution directly on the laryngopharyngeal mucosa.

Group III consisted of twelve animals submitted three times weekly to the application of a mixture of a $0.1 \mathrm{~N}$ hydrochloric acid solution with a solution of pepsin diluted to $1 \mathrm{mg}$ per $1 \mathrm{ml}$ of distilled water, directly on the laryngopharyngeal mucosa.

Group IV consisted of twelve animals submitted twice weekly to the application of a mixture of $0.1 \mathrm{~N}$ hydrochloric acid solution with a pepsin solution diluted to $1 \mathrm{mg}$ per $1 \mathrm{ml}$ of distilled water, directly on the laryngopharyngeal mucosa.

Group V consisted of twelve animals treated with a mixture of $400 \mathrm{mg}$ of sodium nitrate diluted in $300 \mathrm{ml}$ of filtered water and submitted three times weekly to the application of a solution of $0.1 \mathrm{~N}$ hydrochloric acid directly on the laryngopharyngeal mucosa.

Group VI consisted of twelve animals treated with a mixture of $400 \mathrm{mg}$ of sodium nitrate diluted in $300 \mathrm{ml}$ of filtered water and submitted twice weekly to the application of a $0.1 \mathrm{~N}$ hydrochloric acid solution directly on the laryngopharyngeal mucosa.

Group VII consisted of ten animals submitted twice weekly to the application of filtered water directly on the laryngopharyngeal mucosa, serving as control group for this study.

Application was carried out with a common Number 1 brush with soft bristles, using non-traumatic separators to provide direct exposure of the laryngopharyngeal mucosa of the rats. Yellow brushes were used exclusively for applying the acid, tan brushes exclusively for the mixture of acid and pepsin, and blue brushes exclusively for the filtered water. The area of application included the risk mucosa in study, namely, the pharyngeal mucosa, besides the supraglottic laryngeal mucosa. There was no need for anesthesia because the procedure caused no significant discomfort to the animals.

The animals were submitted to applications in series for a period of six months, during which time they received a diet of standard ration, their weights being monitored monthly. After the period of exposure, the rats were euthanized by prolonged anesthesia with endovenous chloral hydrate in lethal doses of two milliliters $(2 \mathrm{ml})$ per kilogram of weight.

The specimens for study were obtained by dissecting the risk mucosa and the parts were removed in toto, similar to the surgical procedure performed in humans. Following removal, the specimens were fixed in formalin for 24 hours and then stored in a 70\% alcohol solution. Slides were prepared and colored with hematoxylin and eosin and set in paraffin.

They were analyzed blindly by two experienced pathologists, who evaluated the presence of inflammatory changes in the laryngeal mucosa, such as ulceration, inflammatory infiltrate and characteristic cellularity, as well as the presence of inflammatory exudate in the laryngeal lumen.

For statistical analysis, the SAS Computer System for Windows (Statistical Analysis System), version 8.02 was used 
(SAS Institute Inc, 1999-2001, Cary, NC, USA). Histological changes were compared using the Fisher Exact Test.

\section{Results}

Two animals were excluded from the study, one from group VI and one from group VII, due to lack of oropharyngeal mucosa in the material analyzed.

Among the groups studied no epithelial changes suggestive of dysplasia, intra-epithelial neoplasia or clearly invasive carcinoma were observed. Inflammatory histological changes were observed in varying degrees, such as the presence of lymphocytes and mast cells. There was also inflammatory infiltrate in the mucosa depending on the substance applied and its frequency. No mucosal ulceration was observed.

Evaluating separately the cells that comprised the inflammatory reaction in the histological findings, greater frequency of lymphocytes was seen in Groups II, III, IV and V, although no statistical difference was observed $(p=0.442)$ (Table 1). The presence of mast cells was more intense in Groups V and VI $(p=0.006)($ Table 2).

TABLE 1 - Comparative analysis of lymphocytes in the Groups (Fisher Test: $\mathrm{p}=0,042$ )

\begin{tabular}{c|c|c|c|c|c|c|c|c}
\hline Limphocytes & Group I & Group II & Group III & Group IV & Group V & Group VI & Group VII & Total \\
& & & & & & & & \\
& 12 & 11 & 11 & 10 & 12 & 9 & 7 & 72 \\
& $(100 \%)$ & $(91.67 \%)$ & $(91.67 \%)$ & $(83.33 \%)$ & $(100 \%)$ & $(81.82 \%)$ & $(77.78 \%)$ & \\
\hline $1-2$ & 0 & 1 & 1 & 2 & 0 & 2 & 2 & 8 \\
& $(0 \%)$ & $(8.33 \%)$ & $(8.33 \%)$ & $(16.67 \%)$ & $(0 \%)$ & $(18.18 \%)$ & $(22.22 \%)$ & \\
\hline Total & 12 & 12 & 12 & 12 & 12 & 11 & 9 & 80 \\
& & & & & & & & \\
\hline
\end{tabular}

TABLE 2 - Comparative analysis of mast cells in the Groups (Fisher Test: $p=0,006$ )

\begin{tabular}{c|c|c|c|c|c|c|c|c}
\hline Mast cells & Group I & Group II & Group III & Group IV & Group V & Group VI & Group VII & Total \\
\hline 0 & 12 & 12 & 12 & 12 & 8 & 8 & 7 & 71 \\
& $(100 \%)$ & $(100 \%)$ & $(100 \%)$ & $(100 \%)$ & $(66.67 \%)$ & $(72.73 \%)$ & $(77.78 \%)$ & \\
\hline 1 & 0 & 0 & 0 & 0 & 4 & 3 & 2 & 9 \\
\hline Total & $(0 \%)$ & $(0 \%)$ & $(0 \%)$ & $(0 \%)$ & $(75,0 \%)$ & $(27.27 \%)$ & $(22.22 \%)$ & \\
& 12 & 12 & 12 & 12 & 12 & 11 & 9 & 80 \\
\hline
\end{tabular}


When the animals' weights was analyzed, statistical difference was found only between Groups V and VI in Time t4, which can be explained by the presence of one animal (Rat
6 of Box 10, Group V), which was quite small in comparison to the others (Figure 1).

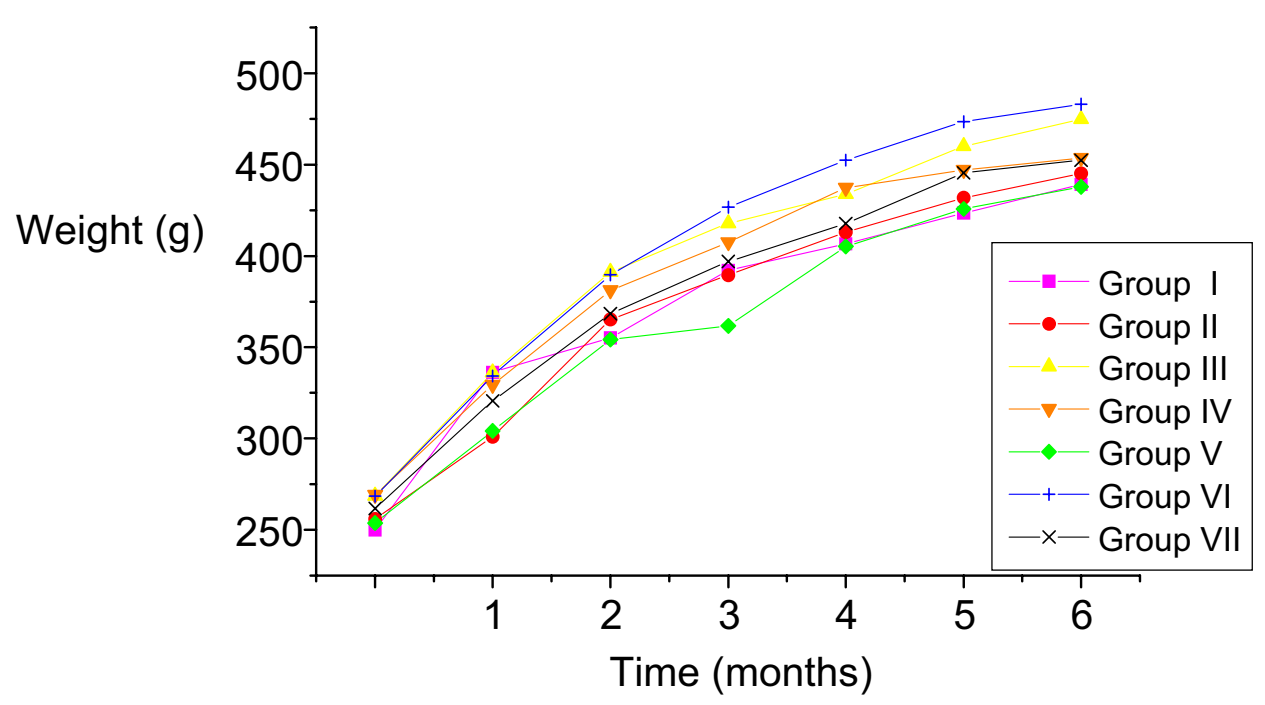

FIGURE 1 - Rats weight (grams) during the study

\section{Discussion}

The relationship between heavy smoking and alcoholism with the etiology of malignant neoplasms in the upper airway and digestive tracts has been well established ${ }^{1-3}$. However, approximately $5 \%$ of patients with head and neck squamous cell carcinoma (SCC) have no history of chronic use of tobacco or alco$\mathrm{hol}^{31}$. This fact seems to reinforce the existence of other factors involved in the genesis of such tumors. One of these co-factors may be the pharyngolaryngeal reflux. A number of authors have shown the co-carcinogenic action of this pathology ${ }^{4-19}$, whose leading irritating agent on the mucosa is the hydrochloric acid.

Sodium nitrate and its derivatives are co-promoters of carcinogenesis, especially the nitrosamine group. The nitrate is absorbed in the small bowels or generated endogenously by nitrous oxide and secreted by the salivary glands. The bacterial flora of the tongue reduces the nitrate into nitrite, and the nitrite, in contact with the acid $\mathrm{pH}$ of nitrous acid, into nitrogenated substances, which, upon reacting with secondary amines, may form $\mathrm{N}$-nitrosamins ${ }^{28}$, which are known to be carcinogenic and often observed in Barrett's esophagus ${ }^{29}$.

Koufman showed that pharyngolaryngeal and gastroesophageal refluxes are different entities, each with its specific symptoms, with infrequent heart burn and regurgitation in the former. Koufman also observed that laryngeal epithelium is more susceptible to tissue injury than is esophageal epithelium ${ }^{32}$.

Olson correlates PLR with inflammatory changes of the upper aerodigestive mucosa and symptoms as throat clearing, laryngeal granuloma, globus pharyngeus, cervical dysphagia and subglottic stenosis ${ }^{33}$. Malfertheiner e Hallerback asso- ciate PLR with respiratory diseases such as chronic coughs, asthma, apnea in sleep and chronic obstructive lung disease ${ }^{34}$. In a clinical study, Koufman analyzed the most prevalent symptoms and laboratory findings in 225 patients with DRGE following examination of esophageal pHmetry. Among the patients studied, symptoms were similar to those described previously but no oropharyngeal SCC was observed. In this same study, the injury mechanisms of hydrochloric acid associated with pepsin in the subglottic mucosa of 20 dogs were experimentally studied. These animals were divided into three groups, with applications of saline solution, pepsin alone, neutralized acid and sodium hydroxide (control group); $0.1 \mathrm{~N}$ hydrochloric acid and mixture of $0.1 \mathrm{~N}$ hydrochloric acid with pepsin diluted to $0.3 \mathrm{mg} / \mathrm{ml}$. It was observed that, in the group submitted to the application of hydrochloric acid, there was greater latency in the healing of the inflammatory process than in the control group, and that there was no healing in the group submitted to the mixture of acid and pepsin ${ }^{35}$.

Mercante and collaborators analyzed 274 patients with CEC in the oral cavity, pharynx and larynx and found $29.3 \%$ of GERD confirmed with digestive endoscopy. Only 92 of these patients were not smokers, but a higher percentage of GERD was found in those with laryngeal CEC $(21.7 \%)$ than in the general population $(5 \%), \mathrm{p}=0.0001$, indicating that the reflux might be considered a co-promoter of carcinogenesis ${ }^{36}$.

Rubin et al..$^{37}$ and Nurgalieva et al. ${ }^{38}$ studied the possible action of Helicobacter pylorii in pharyngolaryngeal carcinogenesis, although these authors presented conflicting results.

The tumorigenic action of hydrochloric acid in high concentrations in the oral mucosa of hamsters was well estab- 
lished in the work of Adams et al. ${ }^{21}$. The authors used five different groups of animals, applying solutions of dimethylbenzathracene (DMBA) associated or not with hydrochloric acid, with and without the addition of porcine pep$\sin$. It was ascertained that the combined action of the hydrochloric acid with the pepsin fostered the emergence of neoplastic lesions of greater dimensions than those in the control group, although less latency time for their appearance was not seen.

Previous works ${ }^{21-25}$ showed clear tumorigenic action of (DMBA) and of other benzene derivatives, as well as the difluoromethylornitine associated with 5-Fluoracil ${ }^{26}$, although currently, due to the high toxicity of these agents, the preference has been to use other solutions.

In the present study, only substances involved in GERD were used, namely, hydrochloric acid in the concentrations found in the organism $(0.1 \mathrm{~N})$, pepsin, and nitrate. Although no preneoplastic changes were found, greater intensity of inflammatory reaction was seen in the groups where sodium nitrate $(p<0.05)$ was applied, with greater tendency in the group with three weekly applications (groups V and VI), confirming its injurious action. Differently from the study by Adams et al. ${ }^{21}$, the synergic effect between acid and pepsin was not observed.

The histological changes found in the oropharyngeal mucosa of rats were based on the paper by Lewis ${ }^{39}$, who described the inflammatory injuries in the larynx of rats submitted to a similar experimentation.

Opposite to the data found in this study, the work by Goldberg et $a .^{22}$, although performed on cats, found more injury in the esophageal mucosa submitted to the application of a mixture with higher concentrations of acid and pepsin, although no pre-neoplastic changes were seen. The study did not involve the use of nitrates. Lillemoe et al. ${ }^{24}$, in an experiment with New Zealand rabbits, ascertained that the pepsin in acid $\mathrm{pH}$ has a more irritating effect on the esophageal mucosa than do trypsin, bile or acid, analyzed separately, also with no dysplastic changes being noted. Again no nitrate was used.

\section{Conclusion}

Applications of a mixture of a $0.1 \mathrm{~N}$ hydrochloric acid solution with a solution of pepsin and sodium nitrate, directly on the laryngopharyngeal mucosa, in groups of Wistar rats, caused inflammatory histological changes of varying degrees, such as the presence of lymphocytes and mast cells, however no epithelial changes suggestive of dysplasia, intra-epithelial neoplasia or clearly invasive carcinoma were seen. The data of the current study could not corroborate the hypothesis that gastroesophageal and pharyngolaryngeal refluxes are carcinogenic factors to the laryngopharyngeal mucosa, and more studies are necessary in the future.

\section{References}

1. Burch JD, Howe GR, Miller AB, Semenciw R. Tobacco, alcohol, asbestos, and nickel in the etiology of cancer of the larynx: a case study. J Natl Cancer Inst. 1981;67(6):1219-24.

2. De Stefani E, Correa P, Oreggia F, Leiva J, Rivero S, Fernandez G,
Deneo-Pellegrini H, Zavala D, Fontham E. Risk factors for laryngeal cancer. Cancer. 1987;60(12):3087-91.

3. Koufman JA, Burke AJ. The etiology and pathogenesis of laryngeal carcinoma. Otolaryngol Clin North Am. 1997;30(1):1-19.

4. Assimakopoulos D, Patrikakos G. The role of gastroesophageal reflux in the pathogenesis of laryngeal carcinoma. Am J Otolaryngol. 2002;23(6):351-7.

5. Bacciu A, Mercante G, Ingegnoli A, Bacciu S, Ferri T. Reflux esophagitis as a possible risk factor in the development of pharyngolaryngeal squamous cell carcinoma. Tumori. 2003;89(5):485-7.

6. Biacabe B, Gleich LL, Lacourreye O, Hatl DM, Bouchoucha M, Brasnu D. Silent gastroesophageal reflux disease in patients with pharyngolaryngeal cancer: further results. Head Neck. 1998;20:510-4. 7. Chen MY, Ott DJ, Casolo BJ, Moghazy KM, Koufman JA. Correlation of laryngeal and pharyngeal carcinomas and 24-hour $\mathrm{pH}$ monitoring of the esophagus and pharynx. Otolaryngol Head Neck Surg. 1998;119(5):460-2.

8. Chen MY, Ott DJ, Casolo BJ, Moghazy KM, Koufman JA. Correlation of laryngeal and pharyngeal carcinomas and 24-hour $\mathrm{pH}$ monitoring of the esophagus and pharynx: retraction. Otolaryngol Head Neck Surg. 1999;121(1):168.

9. Copper MP, Smit CF, Stanojcic LD, Devriese PP, Schouwenburg PF, Mathus-Vliegen LMH. High incidence of laryngo-pharyngeal reflux in patients with head and neck cancer. Laryngoscope. 2000;110:1007-11.

10. Dagli S, Dagli U, Kurtaran H, Alkim C, Sahin B. Laryngopharyngeal reflux in laryngeal cancer. Turk J Gastroenterol. 2004;15(2):7781.

11. El-Serag HB, Hepworth EJ, Lee P, Sonnenberg A. Gastroesophageal reflux disease is a risk factor for laryngeal and pharyngeal cancer. Am J Gastroenterol. 2001;96(7): 2013-8.

12. Freije JE, Beatty TW, Campbell BH, Woodson BT, Schultz CJ, Toohill RJ. Carcinoma of the larynx with gastroesophageal reflux. Am J Otolaryngol. 1996;17(6):386-90.

13. Galli J, Cammarota G, Calo L, Agostino S, D’Ugo D, Cianci R, Almadori G. The role of acid and alkaline reflux in laryngeal squamous cell carcinoma. Laryngoscope. 2002;112(10):1861-5.

14. Galli J, Frenguelli A, Calo L, Agostinho S, Cianci R, Cammarota $\mathrm{G}$. Role of gastroesophageal reflux in precancerous conditions and in squamous cell carcinoma of the larynx: our experience. Acta Otorhinolaryngol Ital. 2001;21(6):350-5.

15. Lewin JS, Gillenwater AM, Garrett JD, Bishop-Leone JK, Nguyen DD, Callender DL, Ayers GD, Myers JN. Characterization of laryngopharyngeal reflux in patients with premalignant or early carcinomas of the larynx. Cancer. 2003;97(4):1010-4.

16. Morrison MD. Is chronic gastroesophageal reflux a causative factor in glottic carcinoma? Otolaryngol Head Neck Surg. 1988;99(4):370-4.

17. Olson NR. Aerodigestive malignancy and gastroesophageal reflux disease. Am J Med. 1997;103(5A):97S-99S.

18. Qadeer MA, Colabianchi N, Strome M, Vaezi MF. Gastroesophageal reflux and laryngeal cancer: causation or association? Am J Otolaryngol. 2006;27(2):119-28.

19. Ward PH, Hanson DG. Reflux as an etiological factor of carcinoma of the larynx. Laryngoscope. 1988;98:1195-9.

20. Adams J, Heintz P, Gross N, Andersen P, Everts E, Wax M, Cohen $\mathrm{J}$. Acid/pepsin promotion of carcinogenesis in the hamster cheek pouch. Arch Otolaryngol Head Neck Surg. 2000;126:405-9.

21 . Delahunty JE, Cherry J. Experimentally produced vocal cord granulomas. Laryngoscope. 1968;78(11):1941-7.

22. Goldberg HI, Dodds WJ, Gee S, Montgomery C, Zboralske FF. Role of acid and pepsin in acute experimental esophagitis. Gastroenterology. 1969;56(2):223-30.

23. Lillemoe KD, Johnson LF, Harmon JW. Role of components of the 
gastroduodenal contents in experimental acid esophagitis. Surgery. 1982;92(2):276-84.

24. Morris AL. Factors influencing experimental carcinogenesis in the hamster cheek pouch. J Dent Res. 1961;40:3-15.

25. Salley JJ. Experimental carcinogenesis in the cheek pouch of the syrian hamster. J Dent Res. 1954;33:253-62.

26. Wattenberg LW, Wiedmann TS, Estensen RD. Chemoprevention of cancer of the upper respiratory tract of the syrian golden hamster by aerosol administration of difluoromethylornithine and 5-fluoracil. Cancer Res. 2004;64:2347-9.

27. Ozlugedik S, Yorulmaz I, Gokcan K. Is laryngopharyngeal reflux an important risk factor in the development of laryngeal carcinoma? Eur Arch Otorhiolaryngol. 2006;263(4):339-43.

28. Winter JW, Paterson S, Scobie G, Preston T, McColl KE. N-nitrosamine generation from ingested nitrate via nitric oxide in subjects with and without gastroesophageal reflux. Gastroenterology. 2007;133(1):164-74.

29. Suzuki H, Iijima K, Scobie G, Fyfe V, McColl KE. Nitrate and nitrosative chemistry within Barrett's oesophagus during acid reflux. Gut. 2005;54(11):1527-35.

30. Wight R, Paleri V, Arullendran P. Current theories for the development of nonsmoking and nondrinking laryngeal carcinoma. Curr Opin Otolaryngol Head Neck Surg. 2003;11(2):73-7.

31. Blot WJ, McLaughlin JK, Winn DM, Austin DF, Greenberg RS, Preston-Martin S, Bernstein L, Schoenberg JB, Stemhagen A, Fraumeni JF Jr. Smoking and drinking in relation to oral and pharyngeal cancer.
Cancer Res. 19881;48(11):3282-7.

32. Koufman JA. Laryngopharyngeal reflux is different from classic gastroesophageal reflux disease. Ear Nose Throat J. 2002;81(9 Suppl 2):7-9.

33. Olson NR. Laryngopharyngeal manifestations of gastroesophageal reflux disease. Otolaryngol Clin North Am. 199;24(5):1201-13.

34. Malfertheiner P, Hallerback B. Clinical manifestations and complications of gastroesophageal reflux disease (GERD). Int J Clin Pract. 2005;59(3):346-55.

35 . Koufman JA. The otolaryngologic manifestations of gastroesophageal reflux disease (GERD): a clinical investigation of 225 patients using ambulatory 24-hour $\mathrm{pH}$ monitoring and an experimental investigation of the role of acid and pepsin in the development of laryngeal injury. Laryngoscope. 1991; 101(4 Pt 2 Suppl 53):1-78.

36. Mercante G, Bacciu A, Ferri T, Bacciu S. Gastroesophageal reflux as a possible co-promoting factor in the development of the squamouscell carcinoma of the oral cavity, of the larynx and of the pharynx. Acta Otorhinolaryngol Belg. 2003;57(2):113-7.

37. Rubin JS, Benjamin E, Prior A, Lavy J. The prevalence of Helicobacter pylori infection in malignant and premalignant conditions of head and neck. J Laryngol Otol. 2003;117(2):118-21.

38. Nurgalieva ZZ, Graham DY, Dahlstrom KR, Wei Q, Sturgis EM. A pilot study of Helicobacter pylori infection and risk of laryngopharyngeal cancer. Head Neck. 2005;27(1):22-7.

39. Lewis DJ. Morphological assessment of pathological changes within the rat larynx. Toxicol Pathol. 1991;19(4):352-57.

\section{Correspondence:}

André Del Negro

Rua Governador Pedro de Toledo, 2157/141

13400-075 Piracicaba - São Paulo Brazil

Phone: (55 19)3432-6935

docdnegro@yahoo.com.br

Conflict of interest: none

Financial source: none

Received: January 21, 2008

Review: February 18, 2008

Accepted: March 17, 2008

\section{How to cite this article}

Del Negro A, Araújo MR, Tincani AJ, Meirelles L, Martins AS, Andreollo NA. Experimental carcinogenesis in oropharyngeal mucosa in rats with hydrochloric acid, sodium nitrate and pepsin Acta Cir Bras. [serial on the Internet] 2008 July-Aug;23(4). Available from URL: http://www.scielo.br/acb

\footnotetext{
*Color figure available from www.scielo.br/acb
} 